\title{
Physical-chemical characterization of yellow mombin (Spondias mombin L.) foam-mat drying at different temperatures
}

\author{
Bheatriz S. M. de Freitas ${ }^{1}$, Maisa D. Cavalcante ${ }^{1}$, Caroline Cagnin ${ }^{2}$, \\ Richard M. da Silva ${ }^{3}$, Geovana R. Plácido ${ }^{1}$ \& Daniel E. C. de Oliveira ${ }^{1}$ \\ ${ }^{1}$ Instituto Federal Goiano/Programa de Pós-Graduação em Tecnologia de Alimentos. Rio Verde, GO. E-mail: bia_silvamcg@hotmail.com - ORCID: \\ 0000-0001-7697-7668; maisadiascavalcante@hotmail.com - ORCID:0000-0001-7135-4525; geovanarochaplacido@yahoo.com.br - ORCID: 0000-0002- \\ 3028-7191; oliveira.d.e.c@gmail.com - ORCID: 0000-0002-3824-994X \\ ${ }^{2}$ Universidade Estadual de Londrina/Programa de Pós-Graduação em Ciência e Tecnologia de Alimentos. Londrina, PR. E-mail: carolinecagnin@gmail.com \\ (Corresponding author) - ORCID: 0000-0002-9961-2589 \\ ${ }^{3}$ Universidade Federal de Viçosa/Programa de Pós-Graduação em Ciência e Tecnologia de Alimentos. Viçosa, MG. E-mail: richard_91@hotmail.com - \\ ORCID: 0000-0003-2932-1038
}

\section{Key words:}

drying kinetics

diffusion

mathematical modeling

\begin{abstract}
A B S T R A C T
The objective of this work was to perform foam-mat drying of yellow mombin pulp, verifying the kinetics and mathematical modeling of the process, and characterizing the obtained product with respect to physical and chemical characteristics, compared with the fresh pulp. Foam-mat drying was carried out with the aid of the foam agent Emustab ${ }^{\oplus}$, at temperatures of $50,60,70$ and $80^{\circ} \mathrm{C}$. The drying data were analyzed and fitted to four mathematical models (Wang \& Singh, Verma, Page and Midilli). Effective diffusion coefficient and activation energy were determined. Titratable acidity, $\mathrm{pH}$, soluble solids content and vitamin $\mathrm{C}$ content, as well as the solubility in water of yellow mombin powder and color variance $\left(\mathrm{L}^{*}, \mathrm{a}^{*}, \mathrm{~b}^{*}\right)$ were analyzed in both fresh and dehydrated pulp. The Wang \& Singh model showed best fit at the temperature of $50^{\circ} \mathrm{C}$, whereas the Midilli model showed the best mathematical fit at temperatures of 60,70 and $80^{\circ} \mathrm{C}$. Net diffusion coefficient and activation energy values were proportional to the drying temperature. Drying of the foam at $60{ }^{\circ} \mathrm{C}$ indicated guarantee of quality of yellow mombin pulp with respect to titratable acidity, $\mathrm{pH}$ and color of the $\mathrm{a}^{*}$ coordinate.
\end{abstract}

\section{Palavras-chave:}

cinética de secagem

difusão

modelagem matemática

\section{Caracterização físico-química de cajá (Spondias mombin L.) seco por camada de espuma em diferentes temperaturas}

\section{R E S U M O}

Objetivou-se realizar a secagem da polpa dos frutos de cajá em camada de espuma, verificando a cinética e modelagem matemática do processo, e caracterizar o produto obtido quanto às características físicas e químicas, sendo estas comparadas à polpa in natura. A secagem foi realizada em camada de espuma, com auxílio do agente espumante emustab, nas temperaturas de $50,60,70$ e $80^{\circ} \mathrm{C}$. Os dados da secagem foram analisados e ajustados por quatro modelos matemáticos (Wang e Singh, Verma, Page e Midilli). Foram determinados o coeficiente de difusão efetiva e energia de ativação. Na polpa in natura e desidratada foram analisados o teor de acidez titulável, $\mathrm{pH}$, teor de sólidos solúveis e teor de vitamina $\mathrm{C}$, assim como a solubilidade em água do pó de cajá e análise de variância da cor (coordenadas de $\mathrm{L}^{*}, \mathrm{a}^{*}$ e $\mathrm{b}^{*}$ ). O modelo Wang e Singh indicou melhor ajuste para a temperatura de $50^{\circ} \mathrm{C}$ e o modelo de Midilli demonstrou o melhor ajuste matemático para as temperaturas de 60,70 e $80^{\circ} \mathrm{C}$. Os valores do coeficiente de difusão líquida e energia de ativação foram proporcionais à temperatura de secagem. A secagem da espuma a 60 ${ }^{\circ} \mathrm{C}$ indicou garantia da qualidade da polpa do cajá para acidez titulável, pH e coloração da coordenada de $\mathrm{a}^{*}$. 


\section{INTRODUCTION}

Yellow mombin (Spondias mombin L.) belongs to the Anacardiaceae family and produces fruits that are grown in tropical areas of America, being known as 'taperebá, 'cajámirim' or 'cajazinho'. Yellow mombin has the form of an ovoid drupe, between 3 and $5 \mathrm{~cm}$ in length, thin yellowish-colored peel and bittersweet taste (Tiburski et al., 2011). Yellow mombin fruits are used in the form of frozen pulps, juices, jellies, ice creams and jams (Janick \& Paull, 2008).

Drying of agricultural products contributes to their conservation, reduces weight and volume occupied during industrialization and commercialization, protects against degradation reactions, and makes them available in any period of the year. In addition, it contributes to the concentration of nutrients because water is removed from the product (Fernandes et al., 2014).

Foam-mat drying is appreciated in foods sensitive to heat, viscous and with high sugar levels, such as fruits and fruit juices. Since this process occurs at lower temperatures of dehydration and for shorter time - because the surface area is larger in comparison to the drying with conventional bed - there is greater preservation of nutritional characteristics (Baptestini et al., 2015). According to Kadam et al. (2009), foam-mat drying contributes to the conservation of nutrients in tomato pulp.

Yellow mombin pulp processing by foam-mat drying can promote the preservation of nutrients in the fruit. Given the above, this study aimed to perform foam-mat drying of yellow mombin pulp, verifying the kinetics and mathematical modeling of the process, and characterize the obtained product with respect to physical and chemical characteristics, compared with the fresh pulp.

\section{Material AND Methods}

Yellow mombin pulp was obtained by pulping fruits from a natural vegetation in the region of Montes Claros de Goiás, Goiás, Brazil (16 $06^{\circ} 20^{\prime \prime} \mathrm{S}$ and 51 $17^{\prime} 11^{\prime \prime} \mathrm{W}$ ), manually harvested from December 2015 to February 2016, and transported in thermal boxes to the Laboratory of Fruits and Vegetables of the Federal Institute of Goiás - Campus of Rio Verde.

The foam was formed using Emustab; purchased at the local market, at $5 \%$ proportion $(\mathrm{m} / \mathrm{m})$. Yellow mombin $(300 \mathrm{~g})$ was added and subjected to agitation in an Arno food mixer for $20 \mathrm{~min}$. Then, the samples were placed in triplicate on aluminum trays $(5 \times 9 \times 20 \mathrm{~cm})$ and taken to the oven at different temperatures.

Samples were dried in forced-air oven at temperatures of 50, 60, 70 and $80^{\circ} \mathrm{C}$. According to Fernandes et al. (2014), $80^{\circ} \mathrm{C}$ is the limit temperature for food dehydration, and lower temperatures are tested aiming at preserving nutrients at the end of the process. The samples were weighed until constant weight at regular intervals $(30 \mathrm{~min})$. The drying process was analyzed using the experimental data presented in Table 1 . The models were applied to the experimental drying data through nonlinear regressions using the computer program Statistica, version 7.0.
Table 1. Mathematical models evaluated to describe the drying process

\begin{tabular}{ll}
\multicolumn{1}{c}{$\begin{array}{c}\text { Model } \\
\text { designation }\end{array}$} & \multicolumn{1}{c}{ Model* $^{*}$} \\
Wang \& Singh & $\mathrm{RX}=1=\mathrm{a} \cdot \mathrm{t}+\mathrm{bt}^{2}$ \\
Verma & $\mathrm{RX}=\mathrm{a} \cdot \exp (-\mathrm{k} . \mathrm{t})+(1-\mathrm{a}) \exp \left(-\mathrm{k}_{1} \cdot \mathrm{t}\right)$ \\
Page & $\mathrm{RX}=\exp \left(-\mathrm{k} \cdot \mathrm{t}^{\mathrm{n}}\right)$ \\
Midilli & $\mathrm{RX}=\mathrm{a} \exp \left(-\mathrm{k} . \mathrm{t}^{\mathrm{n}}\right)+\mathrm{b} . \mathrm{t}$ \\
\hline
\end{tabular}

${ }^{*} \mathrm{RX}$ - Moisture content ratio of the product, dimensionless; $\mathrm{t}$ - Drying time, $\mathrm{h}$; $\mathrm{k}$ - Coefficients of drying; $\mathrm{a}, \mathrm{b}, \mathrm{n}$ - Constants of the models

The representativeness of the models was evaluated based on the coefficient of determination $\left(\mathrm{R}^{2}\right)$ and magnitude of the mean squared deviation (MSD) (Eq. 5).

$$
\mathrm{MSD}=\sqrt{\frac{\sum\left(\mathrm{RX}_{\text {pred }}-\mathrm{RX}_{\mathrm{exp}}\right)^{2}}{\mathrm{n}}}
$$

where:

MSD - mean squared deviation;

RX - moisture ratio predicted by the model;

$\mathrm{RX}_{\text {exp }}^{\text {pred }}$ - experimental moisture ratio; and,

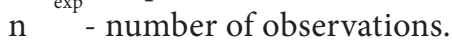

Net diffusion was evaluated using the flat plate model, with approximation of eight terms (Eq. 6) (Brooker et al., 1992). The model was fitted to the experimental data of yellow mombin pulp foam-mat drying, considering the superficial area and volume, according to the following expression:

$$
\mathrm{RX}=\frac{\mathrm{X}-\mathrm{X}_{\mathrm{e}}}{\mathrm{X}_{0}-\mathrm{X}_{\mathrm{e}}}=\frac{8}{\pi^{2}} \sum_{\mathrm{n}_{\mathrm{t}}=0}^{\infty} \frac{1}{\left(2_{\mathrm{n}_{\mathrm{t}}}+1\right)^{2}} \exp \left[\frac{-\left(2 \mathrm{n}_{\mathrm{t}}+1\right)^{2} \cdot \pi^{2} \cdot \mathrm{D} \cdot \mathrm{T}}{4} \cdot\left(\frac{\mathrm{S}}{\mathrm{V}}\right)^{2}\right]
$$

where:

RX - moisture ratio of the product, dimensionless;

$\mathrm{n}$ - number of terms;

$\mathrm{D}^{\mathrm{t}} \quad$ - effective diffusion coefficient, $\mathrm{m}^{2} \mathrm{~s}^{-1}$;

$\mathrm{T}$ - time, h;

S - surface area of the product, $\mathrm{m}^{2}$; and,

$\mathrm{V}$ - volume of the product, $\mathrm{m}^{3}$, obtained by:

$$
\mathrm{V}=\mathrm{W} \cdot \mathrm{L} \cdot \mathrm{T}
$$

where:

W - width, m;

L - length, $\mathrm{m}$; and,

$\mathrm{T}$ - thickness, $\mathrm{m}$.

The surface area of the yellow mombin pulp foam was calculated by measuring length, width and thickness using a digital caliper (Leetools - $150 \mathrm{~mm}, 0.01-\mathrm{mm}$ precision). Then, the area was obtained by multiplying the length $(\mathrm{L})$ by the width $(\mathrm{W})$ of the tray used in the analysis, according to the Eq. 8:

$$
\mathrm{S}=\mathrm{L} \cdot \mathrm{W}
$$

where:

S - tray surface area, $\mathrm{m}^{2}$;

L - length, $\mathrm{m}$; and, 
W - width, $\mathrm{m}$.

The relationship between drying air temperature elevation and effective diffusion coefficient (D) was described by the Arrhenius equation (Eq. 9).

$$
\mathrm{D}=\mathrm{D}_{0} \cdot \exp \left(\frac{-\mathrm{E}_{\mathrm{a}}}{\mathrm{R} \cdot \mathrm{T}_{\mathrm{ab}}}\right)
$$

where:

D - effective diffusion coefficient, $\mathrm{m}^{2} \mathrm{~s}^{-1}$;

$\mathrm{D}_{0}$ - pre-exponential factor, $\mathrm{m}^{2} \mathrm{~s}^{-1}$;

$\mathrm{E}_{\mathrm{a}}^{0}$ - activation energy, $\mathrm{kJ} \mathrm{mol}^{-1}$;

$\mathrm{R}$ - universal gas constant, $8.134 \mathrm{~kJ} \mathrm{kmol}^{-1} \mathrm{~K}^{-1}$; and,

$\mathrm{T} \mathrm{ab}$ - absolute temperature, $\mathrm{K}$.

After drying, the samples were removed from the trays and slightly agitated, manually, to obtain the yellow mombin pulp powder. Powder samples were diluted in distilled water at 1:2 proportion for physical-chemical characterization. Titratable acidity was determined by titrating the filtered juice, through a Unifil filter (150-mm mesh), with $\mathrm{NaOH}$ solution $(0.01 \mathrm{~N})$, and the results were expressed in \% of citric acid according to the method $\mathrm{n}^{\circ} 942.15$ of AOAC (2010). pH was measured using a digital benchtop $\mathrm{pH}$ meter (Luca - $210 \mathrm{P}$, MS Tecnopon) according to the method $n^{\circ} 981.12$ of AOAC (2010). In the quantification of soluble solids content, expressed in ${ }^{\circ} \mathrm{Brix}$, the reading was taken in juice filtered in refractometer (ATAGO PR-101), according to the method $n^{\circ} 932.12$ of AOAC (2010). Ascorbic acid contents were determined by oxidation-reduction volumetric analysis, with titration of yellow mombin samples in 2,6-dichlorophenolindophenol sodium (DCIP), according to the method $n^{\circ} 967.21$ of AOAC (2010). Yellow mombin foam solubility in water was calculated by the difference of weight and expressed on dry basis according to the method described by Cano-Chauca et al. (2005).

Colorimetric evaluation was carried out in HunterLab ColorQuest II spectrophotometer at the Laboratory of Postharvest of Plant Products of the Federal Institute of Goiás, Campus of Rio Verde, measuring the values of luminosity index $\mathrm{L}^{*}$ and chroma indices $\mathrm{a}^{*}$ and $\mathrm{b}^{*}$. The results were expressed in $L^{*}, a^{*}$ and $b^{*}$ values in the following range: $L^{*}$ (luminosity or brightness), from black (0) to white (100), $\mathrm{a}^{*}$ from green $(-60)$ to red $(+60)$, and $b^{*}$ from blue $(-60)$ to yellow $(+60)$.

The results were subjected to analysis of variance (ANOVA) by $\mathrm{F}$ test, followed by means analysis by Tukey test at 0.05 probability level and regression analysis at 0.05 probability level, using the statistical program Sisvar (Ferreira, 2010). The evaluated characteristics were interpreted firstly by grouping the cultivars with dry pulp, followed by comparison of all cultivars.

\section{RESULTS AND DISCUSSION}

The experimental curves of yellow mombin pulp drying for the temperature range from 50 to $80^{\circ} \mathrm{C}$ are presented in Figure 1 . The shortest drying time occurred at temperature of $80^{\circ} \mathrm{C}$. Higher temperature reduces the drying time because of the greater amount of heat transferred from the air to the material, a fact also observed by Baptestini et al. (2015) in soursop foam-mat drying and by Furtado et al. (2010) in red mombin pulp drying.

Different mathematical models were fitted to the data obtained during the drying, to represent the phenomenon (Table 1). The experimental data of yellow mombin pulp drying kinetics and the coefficients of determination $\left(\mathrm{R}^{2}\right)$ and mean squared deviations for the temperatures of $50,60,70$ and $80^{\circ} \mathrm{C}$ are presented in Table 2.

The lower the MSD, the better the fit to the experimental data. Experiments with fruit pulp use this parameter to selection the mathematical models (Feitosa et al., 2017). Among the models tested, Midilli showed the best fit, except for the temperature of $50{ }^{\circ} \mathrm{C}$, in which the best fit was found using the Wang \& Singh model, which showed the highest coefficient of determination $\left(\mathrm{R}^{2}\right)$ and lowest mean squared deviations (MSD).

For soursop foam-mat drying, the Midilli model showed the best fit (Baptestini et al., 2015). Feitosa et al. (2017) reported

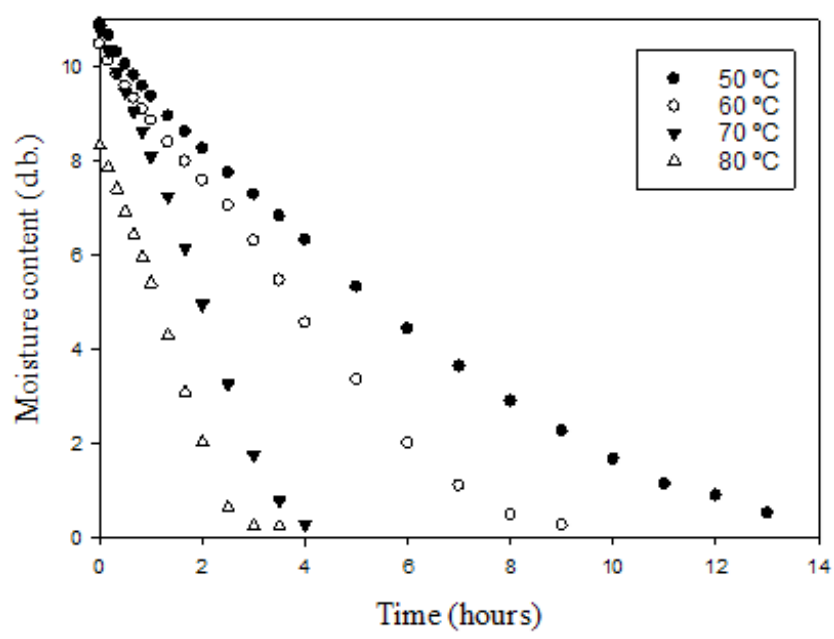

Figure 1. Experimental moisture contents of yellow mombin (Spondias mombin L.) subjected to different drying temperatures

Table 2. Values of coefficient of determination $\left(R^{2}\right)$ and mean squared deviation (MSD), calculated to assess the fit of the mathematical models to the experimental data of yellow mombin (Spondias mombin L.) foam-mat drying at temperatures of $50,60,70$ and $80^{\circ} \mathrm{C}$

\begin{tabular}{|c|c|c|c|c|c|c|c|c|}
\hline \multirow{3}{*}{ Model } & \multicolumn{8}{|c|}{ Temperatures $\left({ }^{\circ} \mathrm{C}\right)$} \\
\hline & \multicolumn{2}{|c|}{50} & \multicolumn{2}{|c|}{60} & \multicolumn{2}{|c|}{70} & \multicolumn{2}{|c|}{80} \\
\hline & MSD & $\mathrm{R}^{2}$ & MSD & $\mathrm{R}^{2}$ & MSD & $\mathbf{R}^{2}$ & MSD & $\mathbf{R}^{2}$ \\
\hline Wang \& Singh & 0.029 & 0.9887 & 0.028 & 0.9898 & 0.078 & 0.9449 & 0.070 & 0.9588 \\
\hline Verma & 0.070 & 0.9992 & 0.091 & 0.8876 & 0.087 & 0.9303 & 0.079 & 0.9476 \\
\hline Page & 0.042 & 0.9757 & 0.029 & 0.9886 & 0.029 & 0.9921 & 0.029 & 0.9929 \\
\hline Midilli & 0.070 & 0.9331 & 0.009 & 0.9988 & 0.022 & 0.9956 & 0.021 & 0.9963 \\
\hline
\end{tabular}


that this mathematical model was the one that best described myrtle pulp foam-mat drying. For carambola drying, Santos et al. (2010) observed that the Page model showed the best fit to the experimental data.

Effective diffusion coefficients for yellow mombin pulp foam-mat drying are shown in Table 3 . The values increased with the elevation in drying air temperature, probably because water removal is faster at higher temperatures.

These data agree with the results of Alves et al. (2016), who studied foam-mat drying of avocado pulp at the same temperatures from 50 to $80^{\circ} \mathrm{C}$. This increasing trend occurs because the diffusivity represents the speed at which water moves from the inside to the surface of the material, being vaporized (Goneli et al., 2014).

According to Kayacier \& Singh (2004), activation energy decreases with the reduction in the water content of the product during its drying. Thus, the activation energy found is an average of the values along the process. The average activation energy was $54.983 \mathrm{~kJ} \mathrm{~mol}^{-1}$, and the activation energy for agricultural products varies from 12.7 to $110 \mathrm{~kJ} \mathrm{~mol}^{-1}$ according to Zogzas et al. (1996), which coincides with the value found in the present study.

The titratable acidity of yellow mombin powder dried at $50{ }^{\circ} \mathrm{C}$ differed from the other treatments (Figure 2A). For the treatment at $50{ }^{\circ} \mathrm{C}$, the yellow mombin powder showed acidity

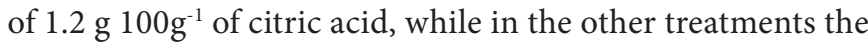

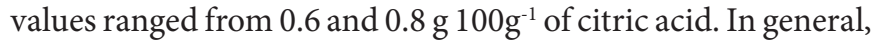
acidity levels do not exceed 1.5 to 2.0\% (Franco, 1998).

The $\mathrm{pH}$ values of yellow mombin powder dried at different temperatures showed significant differences, as shown in Figure $2 \mathrm{~B}$. Elevation of temperature caused a decline in $\mathrm{pH}$ values, except at the temperature of $60^{\circ} \mathrm{C}$, as reported by Abbasi \& Azizpour (2015), who found reduction in $\mathrm{pH}$ values with the increment of temperature in foam-mat drying of sour cherry pulp. Falade \& Okocha (2010) reported similar results for plantain powder using the same method as the present study.

Foam-mat drying caused increment in the contents of soluble solids when compared with the yellow mombin pulp. This characteristic is due to the foaming agent and the dehydration process, which cause concentration of solid substances (Figure 2C). The soluble solids content showed highest value at $60{ }^{\circ} \mathrm{C}$, which contributed to claiming that the greatest water elimination occurred in this situation, confirming the high $\mathrm{pH}$ values and low contents of titratable acids.

The treatment at $80{ }^{\circ} \mathrm{C}$ showed lower concentration of soluble solids, which may indicate that at higher temperature pulp drying is faster and may lead to higher moisture content at the end of the process (Figure 2C). The increase in soluble solids content was reported for the foam-mat drying of genipap and 'araçá-boi' fruits, using the additive Emustab' (Pinto, 2009; Soares, 2009).

Table 3. Net effective diffusion coefficient $\left(\mathrm{m}^{2} \mathrm{~s}^{-1}\right)$ and activation energy $\left(\mathrm{kJ} \mathrm{mol}^{-1}\right)$

\begin{tabular}{|c|c|c|c|c|}
\hline \multicolumn{4}{|c|}{ Temperature $\left({ }^{\circ} \mathrm{C}\right)$} & \multirow[b]{2}{*}{ Ea } \\
\hline $50^{\circ} \mathrm{C}$ & $60^{\circ} \mathrm{C}$ & $70^{\circ} \mathrm{C}$ & $80^{\circ} \mathrm{C}$ & \\
\hline $5.18 \mathrm{E}-09$ & 7.64E-09 & 1.80E-08 & $2.68 \mathrm{E}-08$ & 54.983 \\
\hline \multicolumn{3}{|c|}{$D=-3 \times 10^{-8}+8 \times 10^{-10} \cdot T$} & $R^{2}=0.9508$ & \\
\hline
\end{tabular}

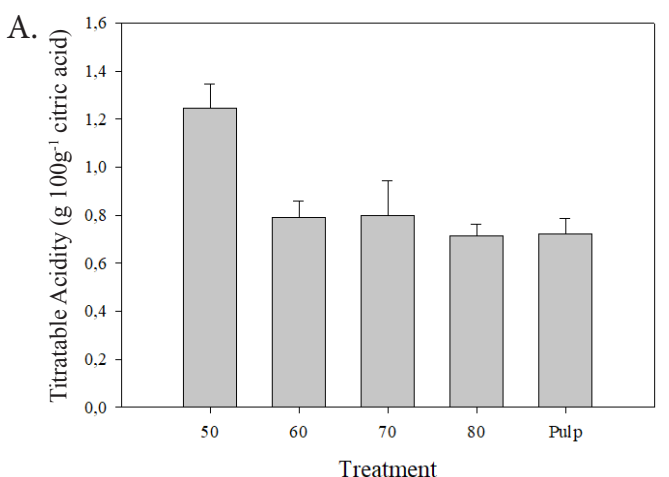

B.

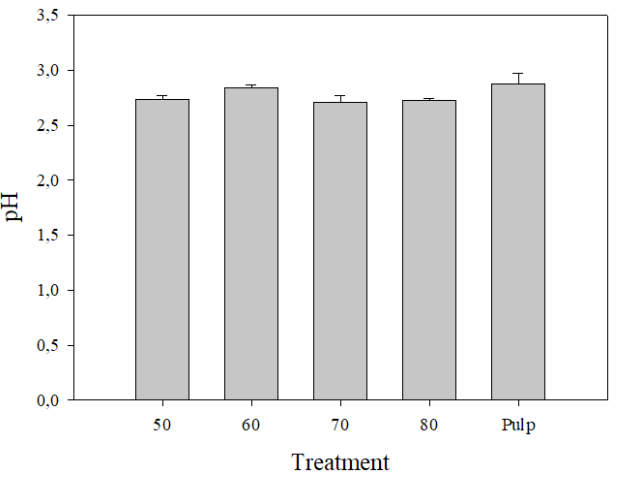

C.
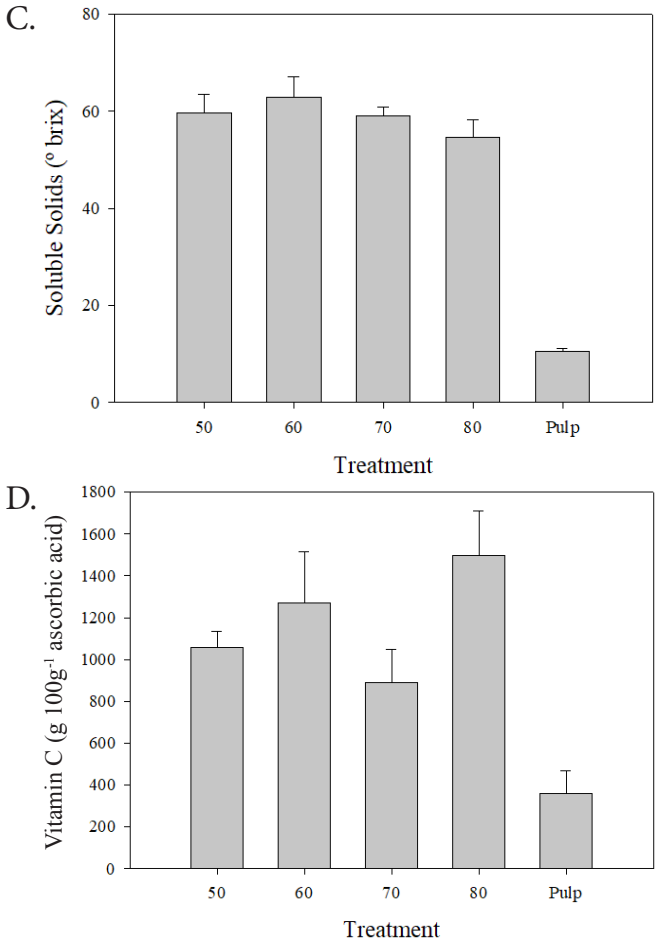

E.

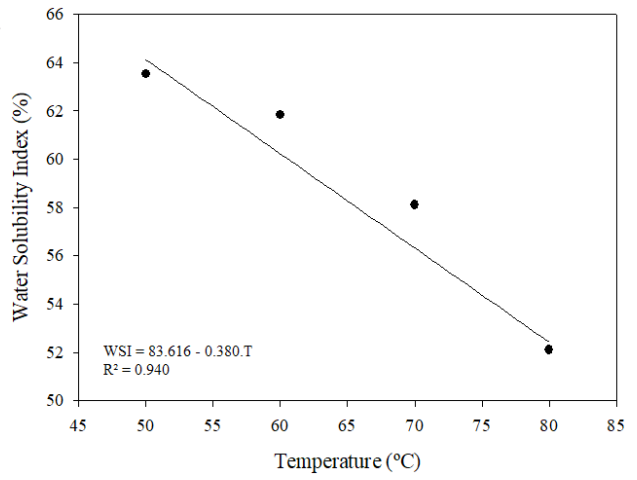

Figure 2. Mean and standard deviation of titratable acidity (A), $\mathrm{pH}(\mathrm{B})$, soluble solids content (C), vitamin $\mathrm{C}$ content (D) and solubility in water (E) of yellow mombin (Spondias mombin. L) dried at different temperatures 
Figure 2D shows the vitamin C content of yellow mombin pulp in the different treatments. There were differences and the highest content of ascorbic acid was found at $80^{\circ} \mathrm{C}$, due to the concentration of substances present in the pulp.

Similar results were reported by Silva et al. (2008) in the dehydration of tamarind pulp by the foam-mat drying method. Drying was carried out at the same temperatures $(50,60,70$ and $80^{\circ} \mathrm{C}$ ) as the present study and the same variations occurred; vitamin $\mathrm{C}$ decreased and increased when all dried pulps were analyzed, with highest value at the temperature of $80^{\circ} \mathrm{C}$.

The longer time for the treatments at 50,60 and $70{ }^{\circ} \mathrm{C}$ may have caused vitamin $\mathrm{C}$ exposure to moisture, light and oxygen, contributing to its degradation, which is due to the sensitivity to heat of the ascorbic acid molecule (Fernandes et al., 2014). Ascorbic acid content decreased in the drying of potato (Mehta et al., 2007) and onion (Kadam et al., 2009) subjected to different treatments of temperature.

According to the solubility in water, as temperature increased there was a reduction in the solubility of yellow mombin powder produced by foam-mat drying (Figure $2 \mathrm{E})$. For the lowest temperature $\left(50^{\circ} \mathrm{C}\right)$, the solubility of the powder is higher because it still contains water molecules in its composition. According to Nadeem et al. (2011), the more stable the drying process, the more bubbles will form in the foam mat, which contributes to porosity and increment in powder's solubility in water. The coefficient of determination indicated good fit of the model $\left(\mathrm{R}^{2}=0.9397\right)$.

Significant differences occurred in the luminosity parameters between the fresh pulp and the pulp dried at different temperatures (Table 4). The results obtained as temperatures increased demonstrated that the drying process led to a darker pulp. Batista et al. (2014) found that the drying of banana samples at various temperatures caused a decline in luminosity, as occurred for yellow mombin pulp samples. Fruits subjected to drying processes become darker due to the non-enzymatic browning and possible losses of pigments (Travaglini et al., 2002).

The characteristic of green (negative values) to red (positive values) color, represented by the coordinate $\mathrm{a}^{\star}$, demonstrates that at higher temperatures there is an increment in $\mathrm{a}^{*}$ values, intensifying the red color. The lowest effect of temperatures, compared with the fresh pulp, occurred for the lowest temperatures ( 50 and $60{ }^{\circ} \mathrm{C}$ ) and, consequently, there was no significant difference between them. This fact was also reported by Medeiros (2007) in the foam-mat drying of mangaba, in which the values of red intensity were proportional to the increase of temperature. Such difference may result from the

Table 4. Color evaluation of samples of yellow mombin (Spondias mombin L.) pulp, fresh and powdered, after foam-mat drying

\begin{tabular}{cccc}
\hline Treatment & \multicolumn{3}{c}{ Parameters } \\
\cline { 2 - 4 } Fresh pulp & $91.51 \mathrm{a}$ & $4.45 \mathrm{a}$ & $23.70 \mathrm{a}$ \\
$50^{\circ} \mathrm{C}$ & $63.02 \mathrm{C}$ & $12.61 \mathrm{~b}$ & $45.40 \mathrm{~d}$ \\
$60^{\circ} \mathrm{C}$ & $64.93 \mathrm{~b}$ & $12.73 \mathrm{~b}$ & $45.28 \mathrm{~d}$ \\
$70^{\circ} \mathrm{C}$ & $45.56 \mathrm{~d}$ & $16.00 \mathrm{C}$ & $42.04 \mathrm{C}$ \\
$80^{\circ} \mathrm{C}$ & $45.61 \mathrm{e}$ & $15.90 \mathrm{C}$ & $29.73 \mathrm{~b}$ \\
\hline
\end{tabular}

*Means followed by lowercase letters differ significantly by Tukey test 0.05 probability level formation of compounds with color close to brownish-red (Reis et al., 2006).

For the coordinate $b^{*}$, varying between yellow and blue, there were variations; however, the lowest temperatures (50 and $60{ }^{\circ} \mathrm{C}$ ) did not differ significantly ( $\mathrm{p} \geq 0.05$ ), tending to cause a yellow color. At temperature of $80^{\circ} \mathrm{C}$, the color was the closest one to that of the fresh pulp.

\section{Conclusions}

1. The Wang \& Singh model showed the best fit at the temperature of $50{ }^{\circ} \mathrm{C}$, whereas Midilli model showed the best fit at temperatures of 60,70 and $80^{\circ} \mathrm{C}$.

2. The characteristics of the foam dried at $60{ }^{\circ} \mathrm{C}$ indicated guarantee of quality of yellow mombin pulp with respect to titratable acidity, $\mathrm{pH}$ and color of the $\mathrm{a}^{*}$ coordinate, and this temperature is considered as the most recommended to maintain the best characteristics of the fresh pulp.

\section{ACKNOWLEDGMENT}

Thanks to FAPEG and the IFGoiano to support this research and for providing equipment and laboratories facilities.

\section{Literature Cited}

Abbasi, E.; Azizpour, M. Evaluation of physicochemical properties of foam mat dried sour cherry powder. LWT - Food Science and Tecnology, v.68, p.105-110, 2015.

Alves, J. J. L.; Rodovalho, R. S. Cinética de secagem em camada de espuma da polpa de abacate cv 'quintal' (Persea Americana Mill). Revista Agrotecnologia, v.7, p.86-98, 2016. https://doi. org/10.12971/2179-5959/agrotecnologia.v7n1p86-98

AOAC - Association of Official Analytical Chemists. Official methods of Analysis. 18.ed. 3.rev. Washington, DC: AOAC, 2010. 1096p.

Baptestini, F. M.; Corrêa, P. C.; Junqueira, M. S.; Ramos, A. M.; Vanegas, J. D. B.; Costa, C. F. Modelagem matemática da secagem de espuma de graviola. Revista Brasileira de Engenharia Agrícola e Ambiental, v.19, p.1203-1208, 2015. https://doi.org/10.1590/18071929/agriambi.v19n12p1203-1208

Batista, D. de V. S.; Cardoso, R. L.; Godoy, R. C. B. de; EvangelistaBarreto, N. S. Estabilidade físico-química e microbiológica de banana passa orgânica. Ciência Rural, v.44, p.1886-1892, 2014. https://doi.org/10.1590/0103-8478cr20130442

Brooker, D. B.; Bakker-Arkema, F. W.; Hall, C.W. Drying and storage of grains and oilseeds. Westport: The AVI Publishing Company, 1992. Chap. 2, 450p.

Cano-Chauca, M.; Stringheta, P. C.; Ramos, A. M.; Cal-Vidal, J. Effect of carriers on the microstructure of mango powder obtained by spray drying and its functional characterization. Innovative Food Science \& Emerging Technologies, v.6, p.420-428, 2005. https:// doi.org/10.1016/j.ifset.2005.05.003

Falade, K. O.; Okocha, J. O. Foam mat drying of plantain and cooking banana (Musa spp.). Food and Bioprocess Technology, v.5, p.11731180, 2010. https://doi.org/10.1007/s11947-010-0354-0

Feitosa, R. M.; Figueirêdo, R. M. F. de; Queiroz, A. J. de. M.; Lima, F. C. dos. S.; Oliveira, E. N. A. de. Drying and characterization of myrtle pulp. Revista Brasileira de Engenharia Agrícola e Ambiental, v.21, p.858-864, 2017. https://doi.org/10.1590/1807-1929/agriambi. v21n $12 \mathrm{p} 858-864$ 
Fernandes, R. V. de B.; Queiroz, F.; Botrel, D. A.; Rocha, V. V.; Souza, V. R. de; Lima, C. F. de. Estudo da adição de albumina e da temperatura de secagem nas características de polpa de tomate em pó. Semina: Ciências Agrárias, v.35, p.1267-1278, 2014. https:// doi.org/10.5433/1679-0359.2014v35n3p1267

Ferreira, D. F. Sistema de análises estatísticas - Sisvar 5.6. Lavras: Universidade Federal de Lavras, 2010.

Franco, G. Tabela de composição química de alimentos. 9.ed. São Paulo: Atheneu, 1998. 307p.

Furtado, G. de F.; Silva, F. S. da; Porto, A. G.; Santos, P. dos. Secagem de polpa de ceriguela pelo método de camada de espuma. Revista Brasileira de Produtos Agroindustriais, v.12, p.9-14, 2010. https:// doi.org/10.15871/1517-8595/rbpa.v12n1p9-14

Goneli, A. L. D.; Vieira, M. do C.; Vilhasanti, H. da C. B.; Gonçalves, A. A. Modelagem matemática e difusividade efetiva de folhas de aroeira durante a secagem. Pesquisa Agropecuária Tropical, v.44, p.56-64, 2014. https://doi.org/10.1590/S1983-40632014000100005

Janick, J.; Paull, R. The enciclopedia of fruit \& nuts. Cambridge: Cambridge University Press, 2008. 68p. https://doi. org/10.1079/9780851996387.0000

Kadam, D. M.; Nangare, D. M.; Oberoi, H. S. Influence of pretreatment on microbial load of stored dehydrated onion slices. International Journal of Food Science and Technology, v.44, p.1902-1908, 2009. https://doi.org/10.1111/j.1365-2621.2009.01980.x

Kayacier, A.; Singh, R. K. Application of effective diffusivity approach for the moisture content prediction of tortilla chips during baking. LWT - Food Science and Technology, v.37, p.275-281, 2004. https://doi.org/10.1016/j.lwt.2003.09.003

Medeiros, J. Secagem de polpa de mangaba em camada de espuma. Campina Grande: UFCG, 2007. 104p. Dissertação Mestrado

Mehta, M. B.; Mehta, B.; Bapodra, A. H.; Joshi, H. D. Effect of germination and heat processing on protein, riboflavin, vit-C and niacin content in peas, cowpea, redgram and wheat. Asian Journal of Home Science, v.2, p.34-38, 2007.
Nadeem, H. S.; Torun, M.; Özdemir, F. Spray drying of the mountain tea (Sideritis stricta) water extract by using different hydrocolloid carriers. LWT - Food Science and Technology, v.44, p.1626-1635, 2011. https://doi.org/10.1016/j.lwt.2011.02.009

Pinto, E. G. Caracterização da espuma de jenipapo (Genipa americana L.) com diferentes aditivos visando à secagem em leito de espuma. Itapetinga: UESB, 2009. Dissertação Mestrado

Reis, R. C.; Ramos, A. M.; Regazzi, A. J.; Minim, V. P. R.; Stringueta, P. C. Almacenamiento de mango secado: Análisis fisicoquímico, microbiológico, color y sensorial. Ciencia y Tecnología Alimentaria, v.5, p.214-225, 2006. https://doi. org/10.1080/11358120609487694

Santos, C. T.; Bonomo, R. F.; Chaves, M. A.; Fontan, R. da C. I.; Bonomo, P. Cinética e modelagem da secagem de carambola (Averrhoa carambola L.) em secador de bandeja. Acta Scientiarum. Technology, v.32, p.309-313, 2010.

Silva, A. S.; Gurjão, K. C. de O.; Almeida, F. de A. C.; Bruno, R. de L. A.; Pereira, W. E. Desidratação da polpa de tamarindo pelo método de camada de espuma. Ciência e Agrotecnologia, v.32, p.18991905, 2008. https://doi.org/10.1590/S1413-70542008000600032

Soares, E. C. Caracterização de aditivos para secagem de araçá-boi (Eugenia stipitata Mc Vaugh) em leito de espuma. Itapetinga: Universidade Estadual do Sudoeste da Bahia, 2009. 88p. Dissertação Mestrado

Tiburski, J. H.; Rosenthal, A.; Deliza, R.; Godoy, R. L. de O.; Pacheco, S. Nutritional properties of yellow mombin (Spondias mombin L.) pulp. Food Research International, v.44, p.2326-2331, 2011. https://doi.org/10.1016/j.foodres.2011.03.037

Travaglini, D. A.; Aguirre, J. M.; Silveira, E. T. F. Desidratação de Frutas. In: Aguirre, J. M.; Gasparino Filho, J. Desidratação de frutas e hortaliças: Manual Técnico. Campinas: ITAL, 2002.

Zogzas, N. P.; Maroulis, Z. B.; Marinos-Kouris, D. Moisture diffusivity data compilation in foodstuffs. Drying Technology, v.14, p.22252253, 1996. https://doi.org/10.1080/07373939608917205 